and D. George (eds.)

\title{
New species of Cirratulidae (Polychaeta) from the northeastern United States
}

\author{
STACY A. DONER and JAMES A. BLAKE \\ ENSR Marine \& Coastal Center, 89 Water Street, Woods Hole, Massachusetts 02543, USA. \\ E-mail: sdoner@ensr.aecom.com
}

\begin{abstract}
SUMMARY: Polychaetes of the family Cirratulidae are common components of the benthic fauna of the northeastern United States. Although several species have been treated by Blake (1991), the true diversity of northeastern Atlantic cirratulids is underestimated since species remain largely undescribed or are erroneously assigned european names. The present paper provides descriptions of three new species of Chaetozone and one new species of Caulleriella. All four of these taxa were collected as part of environmental monitoring programmes in Long Island Sound, Boston Harbor, Massachusetts Bay, and/or Georges Bank from depths ranging from 10 to $200 \mathrm{~m}$. In addition to traditional observations, details provided by the Scanning Electron Microscope (SEM) and staining patterns revealed by Methyl Green are used to further define these taxa and to distinguish them from congeners. Formal descriptions of these new taxa will contribute to a larger understanding of the systematics and interrelationships of the bitentaculate Cirratulidae.
\end{abstract}

Keywords: Polychaeta, Cirratulidae. new species, New England.

RESUMEN: Nuevas especies de CirRatulidae (Polychaeta) Del nordeste de los Estados Unidos. - Los poliquetos de la familia Cirratulidae son componentes comunes de la fauna bentónica del nordeste de los Estados Unidos. Aunque algunas especies han sido tratadas por Blake (1991), la diversidad real de especies de cirratúlidos en ell atlántico nororiental está subestimada pues muchas especies permanecen hoy en día por describir o están erróneamente referidas a nombres de especies europeas. En este trabajo se presenta la descripcíon de tres nuevas especies de Chaetozone y una nueva especie de Caulleriella. Los cuatro taxones fueron recolectados como parte de programas de control ambiental en el estrecho de Long Island, el puerto de Boston, la bahía de Massachusetts, y/o en el Banco Georges en profundidades entre 10 y 200 metros. Para la descripción de los taxones y su caracterización frente a especies próximas, junto a las observaciones tradicionales, se aportan observaciones realizadas al Miscroscopio Electrónico de Barrido así como sobre los patrones de teñido revelados por el Verde de Metilo. Las descripciones formales de estos taxones contribuirán a mejorar el conocimiento sobre la sistemática y las interrelaciones de los Cirratulidae bitentaculados.

Palabras clave: Poliquetos, Cirratulidae, nuevas especies, Nueva Inglaterra.

\section{INTRODUCTION}

The cirratulid fauna of the nearshore and shelf habitats of the northeastern United States is rich with species with many being entirely new to science. Traditional treatment of the cirratulid fauna has resulted in the assignment of european names to local species. Several species were treated by Blake (1991), but the majority of taxa continue to be assigned either provisional or inappropriate names. Species of the genera Caulleriella and Chaetozone are collected in large numbers in water depths of less than $200 \mathrm{~m}$ in Massachusetts waters. Local specimens of Chaetozone have been identified as $C$. setosa, Malmgren 1867, the type-species, originally described from Spitsbergen in the Arctic. Recent examination of benthic infaunal samples from Boston Harbor, Massachusetts Bay, and Georges 
Bank has revealed that specimens provisionally identified as $C$. setosa in monitoring programmes, actually represent three undescribed species.

Two of the three new species of Chaetozone are common in Boston Harbor and Massachusetts Bay, while the third is known only from shelf locations on Georges Bank. The new species of Caulleriella is found in nearshore habitats in Long Island Sound and Massachusetts Bay, but is more common in deeper waters on Georges Bank. Formal descriptions of these four new taxa will contribute to a larger understanding of the systematics and interrelationships of the bitentaculate Cirratulidae of the northeastern United States and the western Atlantic Ocean.

Type specimens of the four new species described in this paper are deposited in the Museum of Comparative Zoology in Cambridge, MA (MCZ) and the National Museum of Natural History, Smithsonian Institution in Washington D.C. (NMNH).

\section{SYSTEMATIC ACCOUNT}

Caulleriella venefica, $\mathrm{n}$. $\mathrm{sp}$.

(Figs. 1, 5B, E)

Material examined. Georges Bank, Cr. M-4 Sta. 5-9, 40³9.9’ N, $67^{\circ} 46.7^{\prime} \mathrm{W}, 84 \mathrm{~m}$, coll. 10 May, 1982, holotype (USNM 1076557); Cr. M-4 sta.5-12, $40^{\circ} 39.0^{\prime} \mathrm{N}, 67^{\circ} 46.1^{\prime} \mathrm{W}, 86 \mathrm{~m}$, coll. 10 May 1982 , 3 paratypes (USNM 1076558); Cr. M-5 Sta. 5-16, 4040.6'N, $67^{\circ} 46.1^{\prime} \mathrm{W}, 78 \mathrm{~m}$, coll. 21 Jul 1982, 2 paratypes (USNM 1076559); Cr. M-5 sta.5-22, $40^{\circ} 39.5^{\prime} \mathrm{N}, 67^{\circ} 43.3^{\prime} \mathrm{W}, 84 \mathrm{~m}$, coll. 21 Jul 1982, 3 paratypes (USNM 1076560); Cr. M-6 sta.5-16, 4040.6’ N, $67^{\circ} 46.1^{\prime} \mathrm{W}, 78 \mathrm{~m}$, coll. 19 Nov 1982, 5 paratypes (USNM 1076561); Cr. M-1 sta. 5-1, $40^{\circ} 39.5^{\prime} \mathrm{N}, 67^{\circ} 46.2^{\prime} \mathrm{W}, 84 \mathrm{~m}$, coll. 6 Jul 1981, 7 paratypes (USNM 1076562)

Description. A moderately-sized species, 11-15 mm long, 0.39-0.47 mm wide for 95-105 chaetigers. Body long, thickened throughout with narrow, crowded segments. Body dorsoventrally flattened with narrow ventral groove. Colour in alcohol light tan to brown. No obvious pigmentation except dark internal area in prostomium and sometimes at its tip. Longitudinal muscles apparent along medial dorsal surface.

Prostomium elongate, narrow, apically pointed (Figs. 1A,B, 5B); eyes absent; nuchal organ, elongate lateral slit, posterior to oral opening (Fig. 5E), carried posteriorly into peristomium (Fig. 5B). Peristomium enlarged, achaetous; surmounted by prominent dorsal crest extending from posterior margin of prostomium to chaetiger 1 (Fig. 5B).
Dorsal tentacles arising from posterior margin of peristomium; first pair of branchiae located on chaetiger 1, dorsal to notochaetae, continuing throughout. Dorsal tentacles thick with ciliated groove; branchiae long, thin.

Parapodia of anterior chaetigers reduced to low rounded lobes; becoming simple tori on segments with hooks. Notochaetae of anterior chaetigers arranged in spreading fascicle of 4-6 capillaries (Fig. 1E); bidentate hooks first present from chaetiger 13-14, completely replacing capillaries; two hooks per notopodium. Neuropodia with bidentate hooks from chaetiger 9-10; two hooks per fascicle in posterior segments with single capillary. Hooks of noto- and neuropodia directed toward each other vis á vis, occurring in pairs, with innermost hook more robust than outer one (Fig. 1C); hooks with apical end curved; apical tooth about one third as long as main fang; hood lacking (Fig. 1F). Interramal notch present on chaetigers bearing hooks. Posterior end narrow, tapering. Pygidium with two short anal cirri ventrally (Fig. 1D).

Etymology. The species name venefica comes from Latin, meaning "Witch" and refers to the resemblance of the anterior end to a witch's hat.

Methyl green staining pattern. Body staining more or less uniform throughout, with no distinct pattern; anterior half of prostomium staining most intensely.

Remarks. Caulleriella venefica has an unusually elongated prostomium and a distinct chaetal armature consisting of pairs of curved, bidentate spines that are directed medially from each ramus, (vis-à-vis). In this respect, the species resembles Chaetozone armata Hartman from California and another new species from off Costa Rica (Harlan Dean, personal communication). The nuchal organ of Caulleriella venefica differs in shape and position from Chaetozone species (see below). In Caulleriella the nuchal organ is a longitudinal slit whereas in Chaetozone species that have been examined, the nuchal organ is circular and has been misinterpreted as an eye by some investigators. Thus the location of the nuchal organ and its shape may be an important generic-level character in some cirratulids.

Distribution. Eastern North America: Long Island Sound, Georges Bank, Massachusetts Bay, 30-85 m. 


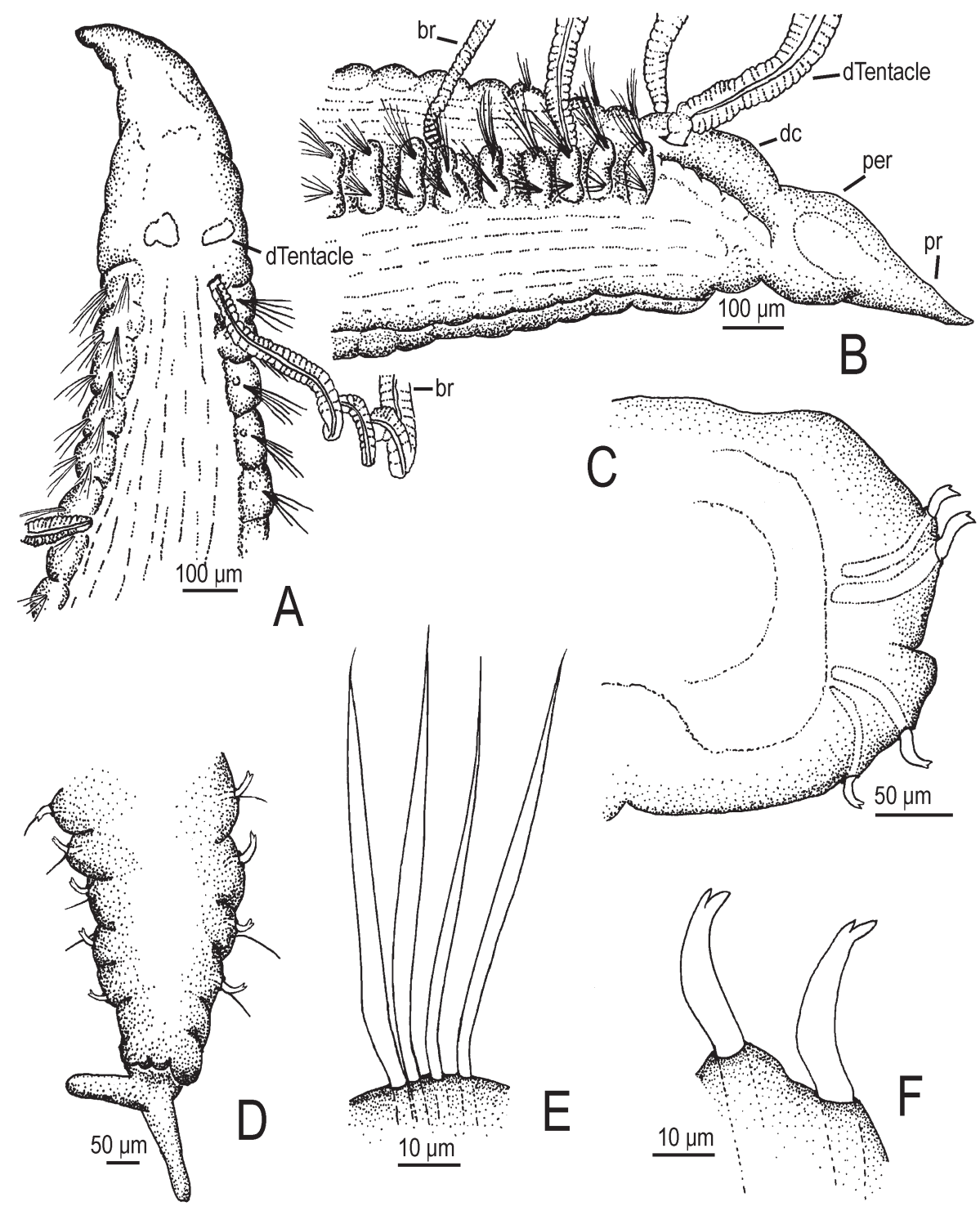

FIG. 1. - Caulleriella venefica (Sta. NF23-1): A, anterior end in dorsal view; B, anterior end in lateral view; C, posterior chaetiger in cross section; D, posterior end in dorsal view; E, notochaetae of anterior chaetigers; F, notopodial hooked chaetae from posterior chaetiger.

\section{Chaetozone anasimus $\mathrm{n} . \mathrm{sp}$.}

(Figs. 2, 5C, G)

Material examined. Massachusetts Bay, collected August 2002; sta. FF11-1, 4265.9'N, 7050.0'W, 89 m, Holotype (MCZ 65293); sta FF14-2, $42^{\circ} 41.7^{\prime} \mathrm{N}, 70^{\circ} 65.5^{\prime} \mathrm{W}, 74 \mathrm{~m}, 6$ paratypes (MCZ 65294); sta. FF11-2, $42^{\circ} 65.9^{\prime} \mathrm{N}, 70^{\circ} 50.0^{\prime} \mathrm{W}, 89 \mathrm{~m}, 10$ paratypes (MCZ $65295) ;$; sta. FF04-2, $42^{\circ} 17.3^{\prime} \mathrm{N}, 70^{\circ} 25.5^{\prime} \mathrm{W}, 90 \mathrm{~m}, 6$ paratypes (MCZ 65296).

Description. A moderately- sized species, 9-12 $\mathrm{mm}$ long, 0.5-1 mm wide for 65-75 chaetigers. Body thick, robust in anterior two-thirds, then tapering posteriorly; body segments narrow, crowded anteriorly; dorsoventrally flattened; shallow midventral groove present. Colour in alcohol light tan, lacking any distinctive body pigments.
Prostomium short, conical, pointed, usually with tip directed dorsally (Figs. 2A,B, 5C); eyes absent; nuchal organ present on lateral surface of peristomium just anterior to oral opening, appearing as longitudinal groove (Fig. 5C, G); supraoesophageal ganglion visible; peristomium with pair of dorsal tentacles; first pair of branchiae positioned laterally to tentacles. Subsequent chaetigers with branchiae dorsal to notochaetae.

Noto- and neurochaetae from chaetiger 1 all capillaries, numbering about 6-8 per fascicle; acicular spines first present from about chaetiger $50-55$ in neuropodia and chaetiger 55-60 in notopodia. In the most posterior chaetigers neuropodial spines numbering 6-10, notopodial spines numbering 10-14; 


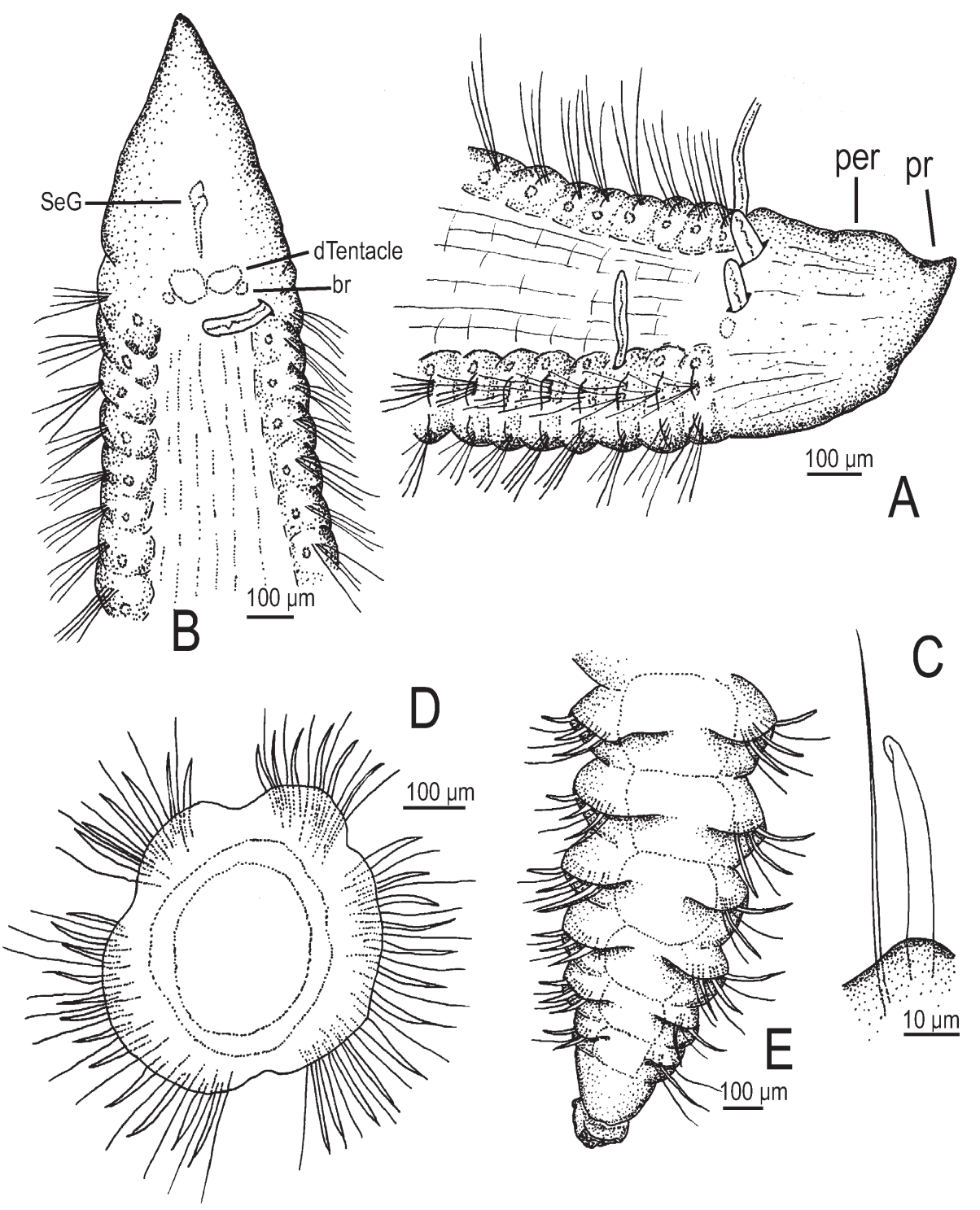

FIG. 2. - Chaetozone anasimus (Paratype Sta. FF14-2, MCZ 65294): A, anterior end in lateral view; B, anterior end in dorsal view; C, spine and capillary from chaetiger 60; D, cross section from near chaetiger 60; E, posterior end in dorsal view.

spines forming only a partial cincture, accompanied by alternating, thin, smooth capillaries (Fig. 2D); spines with pointed tips that bend back to touch shaft of spine (Fig. 2C), sheath apparent. Parapodia reduced to low tori from which chaetal fascicles emerge; these formed into low membranes in far posterior chaetigers bearing cinctures. Pygidium bearing ventral, cuplike lobe (Fig. 2E).

Methyl green staining pattern. Base of prostomium stains most intensely. Remainder of body staining uniformly, with no distinct pattern. Tip of prostomium not staining.

Etymology. The species name anasimus comes from the Latin, meaning with upturned nose and refers to the upturned prostomium.

Remarks. Chaetozone anasimus is found in the sediments of Boston Harbor and Massachusetts Bay along with $C$. hystricosus. Both species have in past ecological surveys been considered as one species. The presence of modified spines with tips that bend back along the shaft in $C$. anasimus distinguish it from the blunt, acicular spines of $C$. hystricosus. The bent tip on the spines of $C$. anasimus is similar to that of $C$. commonalis Blake from California.

Distribution. Eastern North America: Massachusetts Bay, Boston Harbor, 75-84 m. 

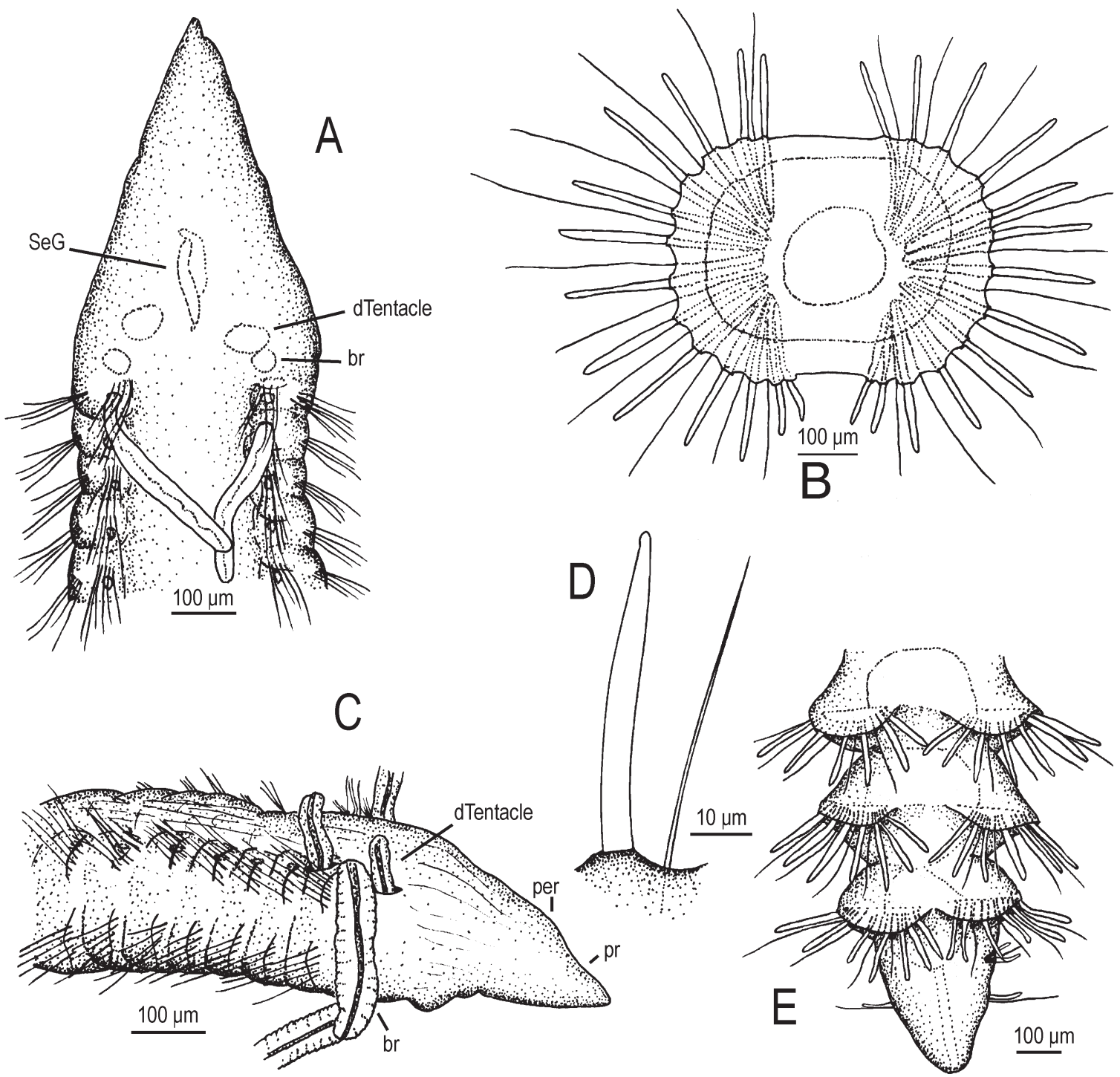

FIG. 3. - Chaetozone hystricosus (Paratype Sta. FF04-2, MCZ 65298): A, anterior end in dorsal view; B, cross section showing full cincture from chaetiger 69; C, anterior end in lateral view; D, spine and capillary from chaetiger 70; E, posterior end in dorsal view.

Chaetozone hystricosus $\mathrm{n}$. sp.

(Figs. 3, 5A, F)

Material examined. Massachusetts Bay, sta. FF14-3, 42 $17.3^{\prime} \mathrm{N}$ $70^{\circ} 25.50^{\prime} \mathrm{W}, 90 \mathrm{~m}$, coll. August 2003, holotype (MCZ 65297); sta. FF04-2, $42^{\circ} 17.3^{\prime}$ N $70^{\circ} 25.50^{\prime} \mathrm{W}, 90 \mathrm{~m}$, coll. August 2002, 10 paratypes (MCZ 65298); sta. FF04-3, 42¹7.3' N 70²5.50’ W, 90 $\mathrm{m}$, coll. August 2003, 10 paratypes (MCZ 65299).

Description. A moderately-sized species, adults 9-15 mm long $0.38-0.45 \mathrm{~mm}$ wide for $70-80$ chaetigers. Colour in alcohol light tan, lacking distinctive body pigment. Body long, somewhat dorsoventrally flattened with midventral groove; body segments crowded anteriorly, less so in posterior chaetigers.
Prostomium long, pointed at anterior end; eyes absent; ciliated, oval nuchal organs present on lateral surface of peristomium just anterior to oral opening (Fig. 5A, F); supraoesophageal ganglion visible with light microscopy (Fig. 3A); peristomium with pair of dorsal tentacles at posterior margin, with first pair of branchiae lateral to tentacles. Subsequent branchiae arising dorsal to notochaetae (Figs. 3A, C).

Noto- and neurochaetae from chaetiger 1 all capillaries, 7-9 in notopodia and 5-7 in neuropodia per fascicle; acicular spines from chaetiger $40-45$ in neuropodia and 45-50 in notopodia. Anterior parapodia reduced to low tori; posterior segments separated by deeply cut intersegmental furrows with highly elevated membranous podial lobes from 
which spines and capillaries emerge. In the most posterior chaetigers, acicular spines 6-7 per fascicle, forming full cincture (Fig. 3B); spines accompanied by alternating, thin, smooth capillaries; acicular spines short, thickened with blunt tips (Fig. 3D). Pygidium simple rounded lobe (Fig. 3E).

Methyl Green Staining Pattern. Body staining more or less uniformly throughout, with no pattern.

Etymology. The species name hystricosus comes from the Latin, meaning prickly or thorny, referring to the appearance of the spiny cinctures in posterior segments.
Remarks. Chaetozone hystricosus is easily confused with $C$. anasimus since they occur together in the same habitat. Examination of the anterior end reveals a circular depression identified on SEM as a nuchal organ. The nuchal organ may be misidentified as an unpigmented eye due to its presence and location on the peristomium. However, it is in fact ciliated, confirming that it is not an eye but a sensory organ. The nuchal organ is also present in $C$. anasimus but is not as readily observed. Of the Chaetozone species examined, $C$. hystricosus most closely resembles $C$. setosa with its full cinctures and form of the acicular spines. The main difference between these two species is the greater number of
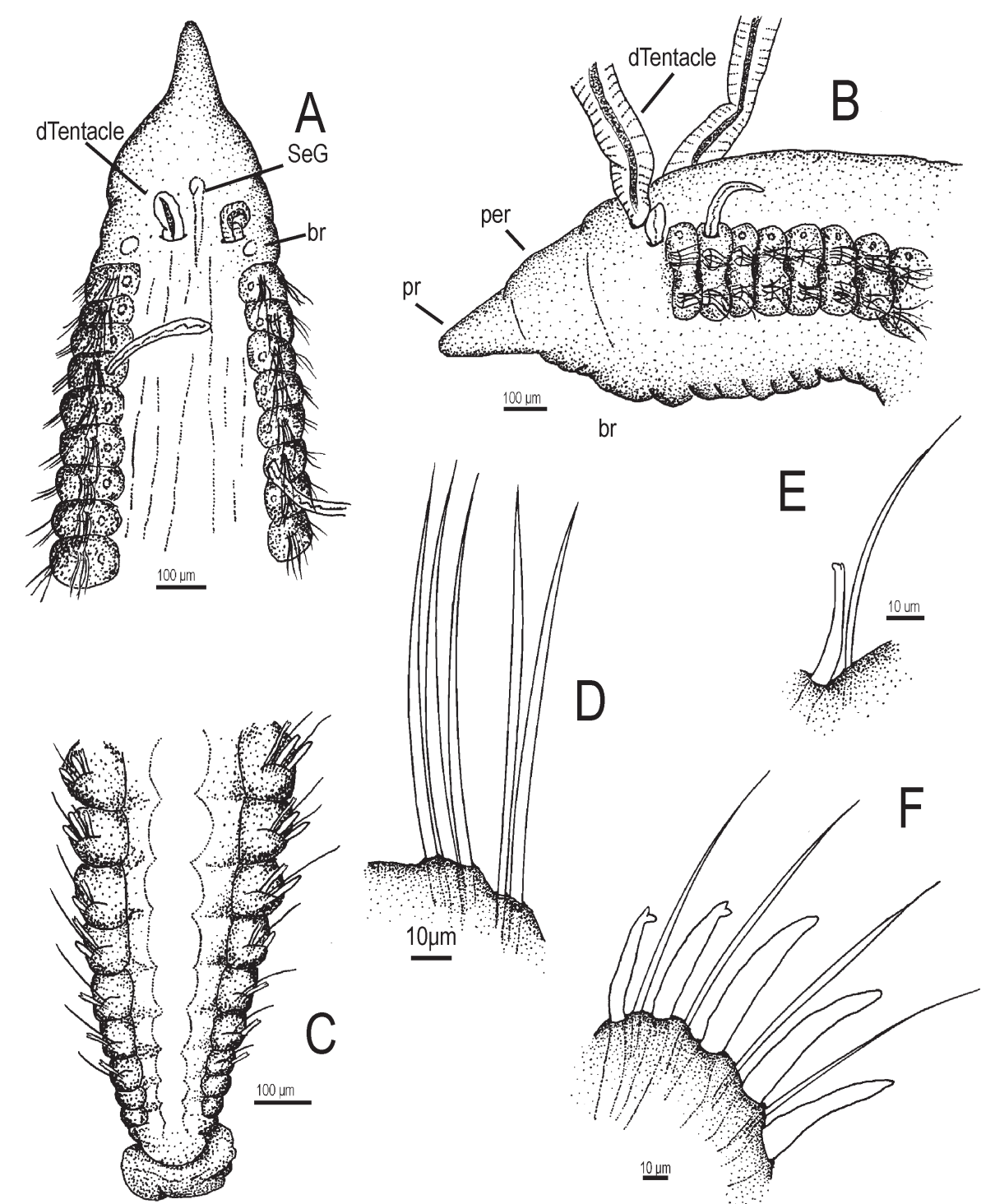

FIG. 4. - Chaetozone diodonta (Paratype Sta.16, USNM 1076552): A, anterior end in dorsal view; B, anterior end in lateral view; C, posterior end in dorsal view; D, notochaetae of anterior chaetiger; E, posterior spine with companion capillary chaeta; F, posterior neuropodium showing spines and hooks. 

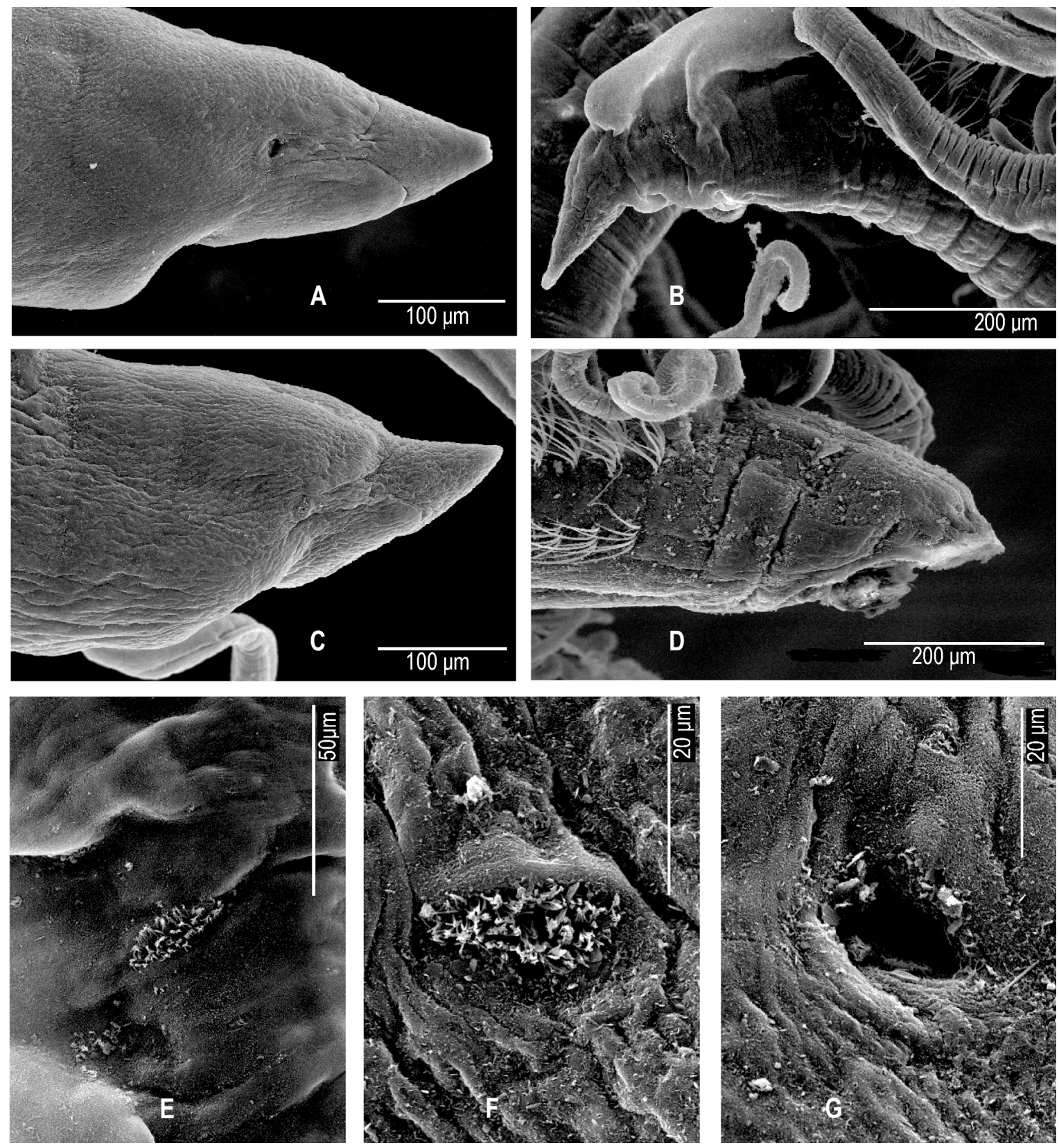

FIG. 5. - A, SEM of Chaetozone hystricosus showing nuchal organ location; B, SEM of Caulleriella venefica; C, SEM of Chaetozone anasimus; D, SEM of Chaetozone diodonta; E, close-up of C. venefica nuchal organ; F, close-up of $C$. hystricosus nuchal organ; $\mathrm{G}$, close-up of $C$. anasimus nuchal organ.

spines, up to fifteen, that occur in the cinctures of $C$. setosa.

Distribution. Eastern North America: Massachusetts Bay, Boston Harbor, 70-100m.

\section{Chaetozone diodonta, $\mathrm{n} . \mathrm{sp}$.}

(Figs. 4, 5D)

Material examined. Georges Bank, Cr. M-6 sta.17 rep4, 40³5.0’ $\mathrm{N}$ $67^{\circ} 11.7^{\prime} \mathrm{W}, 141 \mathrm{~m}$, coll. 19 Nov 1982 , holotype (USNM 1076549) Cr. M-3 sta. $17,40^{\circ} 35.0^{\prime} \mathrm{N}, 67^{\circ} 11.7^{\prime} \mathrm{W}, 141 \mathrm{~m}$, coll. $10 \mathrm{Feb} 1982,5$ paratypes (USNM 1076550); Cr. M-4 sta. 16, 40 $34.2^{\prime} \mathrm{N}$, $67^{\circ} 12.3^{\prime} \mathrm{W}, 142 \mathrm{~m}$, coll. 10 May 1982, 4 paratypes (USNM

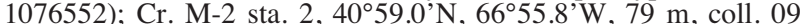
Nov 1981, 4 paratypes (USNM 1076553); Cr. M-4 sta. 16, $40^{\circ} 34.2^{\prime} \mathrm{N}, 67^{\circ} 12.3^{\prime} \mathrm{W}, 142 \mathrm{~m}$, coll. 10 May 1982, 3 paratypes

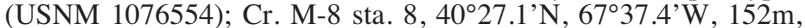
coll. 13 May 1983, 3 paratypes (USNM 1076555).

Description. A moderate-sized species, 5.8-9.0 $\mathrm{mm}$ long, 0.6-0.8 mm wide for 100 chaetigers. Body of uniform thickness throughout with midventral groove, dorsoventrally flattened posteriorly. Colour in alcohol light tan, lacking distinctive body pigment. 
TABLE 1. - Comparative morphology for species of Chaetozone.

\begin{tabular}{|c|c|c|c|c|c|c|c|}
\hline & $\begin{array}{l}\text { Prostomium } \\
\text { shape }\end{array}$ & $\begin{array}{l}\text { Origin of } \\
\text { first } \\
\text { branchiae }\end{array}$ & $\begin{array}{l}\text { Chaetal } \\
\text { type }\end{array}$ & $\begin{array}{c}\text { Origin of } \\
\text { modified chaetae }\end{array}$ & Cinctures & $\begin{array}{l}\text { No. of spines } \\
\text { in posterior } \\
\text { chaetigers }\end{array}$ & Pygidium \\
\hline Chaetozone setosa ${ }^{l}$ & $\begin{array}{l}\text { short, conical, } \\
\text { pointed }\end{array}$ & $\begin{array}{l}\text { posterior to } \\
\text { tentacles on } \\
\text { peristomium }\end{array}$ & $\begin{array}{l}\text { acicular } \\
\text { spines }\end{array}$ & $\begin{array}{c}\text { chaetiger } 40 \\
\text { in neuropodia, } \\
\text { chaetiger } 50 \text { in } \\
\text { notopodia }\end{array}$ & full & $\begin{array}{l}6 \text { to } 8 \text { in both } \\
\text { noto and } \\
\text { neuropodia }\end{array}$ & $\begin{array}{l}\text { small, flat, } \\
\text { rounded } \\
\text { ventral lobe }\end{array}$ \\
\hline Chaetozone anasimus & $\begin{array}{l}\text { short, conical, } \\
\text { pointed }\end{array}$ & $\begin{array}{l}\text { positioned } \\
\text { laterally to } \\
\text { tentacles }\end{array}$ & $\begin{array}{l}\text { spines w/ tips } \\
\text { pointed, } \\
\text { bending back } \\
\text { to touch shaft } \\
\text { of spine }\end{array}$ & $\begin{array}{c}\text { chaetiger } 50-55 \\
\text { in neuropodia, } \\
\text { chaetiger } 55-60 \text { in } \\
\text { notopodia }\end{array}$ & partial & $\begin{array}{l}6 \text { in neuropodia, } \\
12 \text { in notopodia }\end{array}$ & cup-like \\
\hline Chaetozone hystricosus & long, pointed & $\begin{array}{l}\text { positioned } \\
\text { laterally to } \\
\text { tentacles }\end{array}$ & $\begin{array}{l}\text { acicular spines, } \\
\text { thickened }\end{array}$ & $\begin{array}{l}\text { chaetiger } 40-45 \\
\text { in neuropodia, } \\
\text { chaetiger } 45-50 \text { in } \\
\text { notopodia }\end{array}$ & full & $\begin{array}{l}6 \text { to } 7 \text { in both } \\
\text { noto and } \\
\text { neuropodia }\end{array}$ & $\begin{array}{l}\text { simple } \\
\text { rounded lobe }\end{array}$ \\
\hline Chaetozone diodonta & long, conical & $\begin{array}{l}\text { positioned } \\
\text { laterally to } \\
\text { tentacles }\end{array}$ & $\begin{array}{l}\text { bidentate hooks } \\
\text { and robust } \\
\text { spines }\end{array}$ & $\begin{array}{c}\text { neurohooks } \\
\text { chaetiger } 11-15, \\
\text { notohooks } \\
\text { chaetiger } 90, \\
\text { neurospines } \\
\text { laetiger } 61 \text {, notospines } \\
\text { chaetiger } 67\end{array}$ & partial & $\begin{array}{l}3 \text { spines, } \\
3 \text { hooks, s } \\
\text { single hook } \\
\text { only in last } \\
10 \text { chaetigers }\end{array}$ & $\begin{array}{l}\text { flattened, } \\
\text { saucer-like lobe }\end{array}$ \\
\hline
\end{tabular}

1. Based on lectotype: Stockholm Museum of Natural History, No. 1493-03. (Designated by M.E. Petersen, 1999).

Prostomium conical, one-third longer than wide (Fig. 4A, B); eyes absent; nuchal organ oval, elongate (Fig. 5D). Peristomium as long as wide. Dorsal tentacles arising from posterior part of peristomium, first branchiae anterior to chaetiger 1, lateral to dorsal tentacles (Fig. 4A, B). Subsequent pairs of branchiae on following segments positioned dorsal to and slightly posterior to notochaetae (Fig. 4B).

Noto- and neuropodia reduced to low tori bearing chaetal fascicles. Notochaetae of anterior chaetigers simple, smooth capillaries, 7-8 per fascicle (Fig. 4D); robust spines from chaetiger 65-70 with addition of bidentate hooks at chaetiger 90; posterior spines not forming well-developed cinctures (Fig. 4D). Neurochaetae of first chaetigers simple capillaries, 5-6 per fascicle with transition to bidentate hooks by chaetiger 15 and addition of robust spines by chaetiger 60 (Fig. 4E, F); chaetae of last ten fascicles of body reduced to single capillary and hook. Pygidium a flattened, saucer-like, lobe (Fig. 4C).

Methyl green staining pattern. Body staining more or less uniform throughout, with no pattern; prostomium and pygidium retain no stain.

Etymology. The species name diodonta comes from the Greek, meaning two-toothed, referring to the presence of the bidentate hooks that accompany acicular spines.
Remarks. Chaetozone diodonta differs from other species found in the northeastern Atlantic in that it has both bidentate hooks and spines in its chaetigers. Typically, hooks are found in Caulleriella species whereas spines are found in Chaetozone species. The transition of the chaetae from hooks to spines and back to hooks poses some question as to the generic classification of this species. The location and shape of the nuchal organ resembles that of a Chaetozone. The noto- and neuropodia are also not widely separated as seen in Caulleriella, suggesting that it is in fact a Chaetozone. C. diodonta resembles $C$. lunula, Blake from California, with both species having spines and hooks.

Distribution. Eastern North America: Georges Bank, 100-160 m.

\section{DISCUSSION}

The bitentaculate cirratulid fauna of the northeastern United States is rich with species, yet the majority of taxa are known by inappropriate european names or provisional names assigned in local monitoring programmes. In addition, several distinct species are believed to be lumped under single names. The first effort to deal with this problem was by Blake (1991) who redefined the genus Tharyx and redescribed its type-species T. acutus Webster and 
Benedict. Blake (1991) also established the genus Aphelochaeta and resurrected the genus Monticellina Laubier, both of which were assigned species formerly included in Tharyx. Numerous additional species of Aphelochaeta are known from the area and species of Monticellina are now believed to be more complex than reported by Blake (1991). The genera Caulleriella and Chaetozone, not included in Blake (1991), are nevertheless well represented in the nearshore and shelf sediments off New England. The four species described in this paper contribute to a larger assessment of the cirratulid fauna of the offshore regions of the western North Atlantic.

The three Chaetozone species reported in this paper suggest that new characters associated with segmentation patterns and branchial distribution, details of posterior spines, and placement and form of the nuchal organs may be important in developing a phylogenetic analysis of the family in general. Some of these issues, especially those dealing with anterior segmentation and branchial distribution, are considered by Blake (2006) in a companion paper in this volume. Chaetal distribution patterns and the nature of the nuchal organs are considered in more detail for the New England species (Table 1).

Chaetozone setosa Malmgren, the type species of Chaetozone, is well-known for the cinctured nature of its posterior acicular spines (Chambers, 2000). In this species, the spines are so numerous that there are only small gaps dorsally, ventrally, and laterally in the fascicles to indicate where the noto- and neurochaetal fascicles begin and end. For the three Chaetozone species described in the present paper, the cinctures are not as extreme as in C. setosa and there are differences in the nature of the spines and sometimes with the companion chaetae. C. hystricosus has welldeveloped cinctures, whereas $C$. anasimus and $C$. diodonta have fewer chaetae with the noto- and neurochaetal fascicles clearly distinct from one another. $C$. diodonta is the most distinctive of the group with both bidentate hooks and robust spines included among the posterior chaetae. Most species of the genus Chaetozone typically have only unidentate acicular posterior spines, bidentate hooks being reserved for species of the genus Caulleriella. A similar situation was found in $C$. bansei Blake from California (Blake, 1996). In C. anasimus, the tips of the posterior spines bend back and are fused with the shaft. This arrangement is known for $C$. curvata HartmannSchröder from Chile, C. commonalis Blake from shelf and upper slope depths from California, and a new deep-water species, also from California (Hartmann-Schröder, 1965; Blake, 1996; 2006). These four taxa thus appear to represent a closelyrelated species group within the genus Chaetozone.

Nuchal organs appear to vary more between genera than species. For example, nuchal organs of species of Chaetozone observed in this paper are small, circular or oval structures, whereas those of Caulleriella venefica are elongated slits. The four species of Chaetozone treated by Blake (2006) in this volume provide similar observations on nuchal organ structure. Although these observations are too few to draw larger conclusions, the structure and placement of the nuchal organs may prove useful in a phylogenetic analysis of cirratulids. In some bitentaculate cirratulids what are described as eyes are most likely nuchal organs.

\section{ACKNOWLEDGMENTS}

We are indebted to Jason Williams, Hofstra University, for preparing the SEMs. Samples from Boston Harbor and Massachusetts Bay were collected as part of the Harbor and Outfall Monitoring Program funded by the Massachusetts Water Resources Authority (MWRA). This work was supported by NSF Grant No. DEB-0118693 (PEET) to James A. Blake, University of Massachusetts.

\section{REFERENCES}

Blake, J.A. - 1991. Revision of some genera and species of Cirratulidae from the Western North Atlantic. Ophelia, Suppl. 5: $17-30$.

Blake, J.A. - 1996. Family Cirratulidae. In: J.A. Blake, B. Hilbig and P.H. Scott (eds.), Taxonomic Atlas of the Santa Maria Basin and Western Santa Barbara Channel. Vol. 6. Annelida Part 3. Polychaeta: Orbiniidae to Cossuridae. pp, 263-384. Santa Barbara Museum of Natural History, California.

Blake, J.A. - 2006. New Species and Records of Deep-Water Cirratulidae (Polychaeta) from off Northern California. Sci. Mar., 70S3: 45-57.

Chambers, S.J. - 2000. A redescription of Chaetozone setosa Malmgren, 1867 including a definition of the genus, and a description of a new species of Chaetozone (Polychaeta: Cirratulidae) from the northeast Atlantic. Bull. Mar. Sci. 67: 587-596.

Hartmann-Schröder, G. - 1965. Die Polychaeten des Eulitorals. In: Hartmann-Schröder, G. und G Hartmann, Zur Kenntnis des Eulitorals der chilenischen Pazifkküste und der argentinischen Küste Südpatagoniens uner besonderer Berücksichtigung der Polychaeten und Ostracoden. Mitt. Hamb. Zool. Mus. Inst., Suppl. 60: 57-167.

Petersen, M.E. - 1999. Reproduction and development of Cirratulidae (Annelida: Polychaeta). Hydrobiologia, 402: 107-128.

Received September 15, 2004. Accepted May 11, 2005. 